\title{
PENGARUH JENIS AIR RENDAMAN TERHADAP PENURUNAN KADAR FORMALIN PADA IKAN TONGKOL (Euthynnus affinis)
}

Devi Arifatin Givanti, Narwati, Margono

\begin{abstract}
Fish is an example of perishable food. To prevent fish from deteriorating quickly, proper handling is required during storage to extend the shelf life, among other things, one of which is by the addition of preservatives. the extension of food shelf lives, people often misused formaldehyde as a food preservative. Formaldehyde itself is banned for use as food ingredients as it may be harmful to human health, such as irritation of the stomach, its carcinogenic properties (causing cancer), and may bring about death.

This was an experimental study using one group pretest-posttest design to investigate the effect of soaking water on the reduction of formaldehyde levels in cobs. There were 48 samples in 6 replications of each treatment group. The dependent variable in this study was the formaldehyde levels in cobs and the independent variables was the type of soaking water (tap water, hot water at temperature of $50{ }^{\circ} \mathrm{C}$ and $5 \%$ vinegar), soaking were exercised for 30 minutes. The data were analyzed using paired test and Anova test.

The result showed that all three types of soaking water were able to reduce levels of formaldehyde in cobs, where tap water reduced formaldehyde level by $53.7 \%$ at $p<a(0.05)$, hot water at temperature of $50^{\circ} \mathrm{C}$ reduced formaldehyde level by $62.6 \%$ at $p<a(0.05)$, and vinegar $5 \%$ reduced formaldehyde level by $42.4 \%$ at $p<a(0.05)$. The Anova test between treatment groups indicated that soaking water resulted in a value of $p>a(0.05)$

It can be concluded that types of soaking water have no effect on the reduction of formaldehyde level in cobs. However, there were significant differences in reduction of formaldehyde level before and after the soaking treatment. The stydy suggested that further research needs to be conducted on other fish samples using different concentration of soaking water and soaking time.
\end{abstract}

\section{Keywords : Formaldehyde, soaking water,cob}

\section{PENDAHULUAN}

Ikan merupakan salah satu contoh bahan makanan mentah yang cepat mengalami pembusukan (perishable food), Agar ikan tidak cepat membusuk maka perlu dilakukan penanganan selama penyimpanan untuk memperpanjang masa simpan yang lebih lama, salah satunya adalah dengan cara penambahan bahan pengawet (Mukono,2010: 152).

Ikan tongkol merupakan salah satu ikan yang bernilai ekonomis tinggi. Jumlah Tangkapan ikan Tongkol yang lebih tinggi dari tingkat konsumsi mengakibatkan terjadi penumpukan pada tangkapan ikan tongkol sehingga perlu penanganan penyimpanan agar memilki masa simpan yang lebih lama.

Menurut Peraturan Menteri Kesehatan Republik Indonesia Nomor 033 Tahun 2012 Tentang Bahan Tambahan Pangan terdapat beberapa jenis bahan tambahan yang dilarang penggunaannya dalam makanan dikarenakan dapat membahayakan kesehatan manusia, seperti halnya formalin. Dikarenakan sifat formalin sebagai anti mikroba yang dapat membunuh bakteri, virus, jamur, dan benalu yang efektif pada konsentrasi tinggi (Cahyadi, 2009: 256) sehingga masyarakat menyalahgunakan formalin untuk mengawetkan makanan agar memiliki daya simpan yang lebih lama, hal ini diperjelas dengan penelitian yang telah dilakukan oleh Teddy (2007) bahwa bakso tanpa penambahan formalin memiliki masa simpan 1 hari, namun pada bakso yang direbus dengan formalin $250 \mathrm{ppm}$ memiliki umur simpan 6 hari.

Hasil pemeriksaan kepolisian Bangka Belitung di kapal ikan didapatkan bahwa dari 7 jenis sampel ikan didapat 4 jenis ikan mengandung formalin, diantaranya ikan tongkol, ikan tenggiri,ikan selayang dan ikan karang babai (Indosiar.com, 2009). Dengan melihat kenyataan penggunaan formalin pada bahan makanan masih terus dilakukan, maka dari itu perlu dilakukan upaya untuk mengurangi kadar formalin dalam makanan, seperti dengan cara merendam bahan makanan dalam air rendaman. Tujuan penelitian ini adalah menghitung dan mebandingkan penurunan kadar formalin pada ikan tongkol setelah dilakukan perendaman pada 3 jenis air rendaman (air PDAM, air panas suhu 50 OC, air cuka $5 \%$ ) serta menganalisis pengaruh jenis air rendaman terhadap penurunan kadar formalin pada ikan tongkol (Euthynnus affinis).

\section{METODE PENELITIAN}

Penelitian ini merupakan penelitian eksperimen dengan rancangan one group pretest posttest. Sampel yang digunakan sebanyak 48 sampel dengan pengulangan sebanyak 6 kali tiap kelompok perlakuan. Pengambilan sampel secara purposif dengan pertimbangan ikan tongkol segar yang digunakan sebagai sampel memiliki bobot \pm 500 gram dan kondisi ikan 
tongkol segar untuk semua sampel dianggap sama.

Variabel terikat dalam penelitian ini adalah kadar formalin pada ikan tongkol. Variabel bebasnya adalah jenis air rendaman (air $\mathrm{PDAM}_{i}$ air panas suhu $50{ }^{\circ} \mathrm{C}$ dan air cuka $5 \%$ ) dengan periakuan perendaman selama 30 menit. Variabel penggangu dalam penelitian ini adalah waktu perendaman, konsentarasi air rendaman dan suhu air rendaman.

Teknik pengumpulan data berdasarkan hasi laboratorium mengenal kadar formalin pada ikan tongkol sebelum dan sesudah dilakukan perlakuan perendaman. Analisis data dalam penelitian ini menggunakan uji paired t test dan uji anova.

\section{HASIL PENELITIAN DAN PEMBAHASAN}

Dari hasil pemeriksaan kadar formalin pada ikan tongkol sebelum dan sesudah dilakukan perlakuan perendaman pada 3 jenis air rendaman (air PDAM, Air Panas suhu $50{ }^{\circ} \mathrm{C}$, air cuka $5 \%$ ) dapat diuraikan dalam tabel berikut:

\section{Perbedaan Penurunan Kadar Formalin Ikan Tongkol Pada Rendaman Air PDAM}

Tabel.1

PENURUNAN KADAR FORMALIN IKAN TONGKOL SEBELUN DAN SESUDAH PERENDAMAN DENGAN AIR PDAM

\begin{tabular}{|r|c|c|c|c|}
\hline \multirow{2}{*}{ No. } & \multicolumn{2}{|c|}{$\begin{array}{c}\text { Kadar Formalin Pada Ikan } \\
\text { Tongkol (mg/Kg) }\end{array}$} & $\begin{array}{c}\text { Perbedaan Kadar Formalin } \\
\text { Sebelum dan Sesudah }\end{array}$ & $\begin{array}{c}\text { Penurunan Kadar Formalin } \\
\text { Sebelum dan Sesudah } \\
\text { Perendaman (\%) }\end{array}$ \\
\cline { 2 - 4 } & Sebelum (A) & Sesudah (A1) & Perendaman & 59.4 \\
\hline 1. & 212.00 & 86.24 & 125.76 & 56.3 \\
\hline 2. & 131.20 & 57.28 & 73.92 & 25.5 \\
\hline 3. & 174.56 & 129.92 & 44.64 & 45.1 \\
\hline 4. & 196.00 & 107.54 & 88.46 & 60.9 \\
\hline 5. & 209.60 & 81.76 & 127.84 & 75.5 \\
\hline 6. & 196.08 & 48.00 & 148.08 & 53.7 \\
\hline $\begin{array}{r}\text { Rata- } \\
\text { rata }\end{array}$ & 186.88 & 85.12 & 101.76 & \\
\hline
\end{tabular}

Berdasarkan uji Paired t test diperoleh hasil $\mathrm{P}=0.001<\mathrm{a}(0.05)$ yang menunjukkan bahwa ada perbedaan penurunan secara signifikan antara kadar formalin pada ikan tongkol sebelum dan sesudah perlakuan perendaman pada air PDAM.

Air PDAM dapat menurunkan kadar formalin pada ikan tongkol dikarenakan air dapat melarutkan senyawa organik yang mempunyai gugus karboksil/ amino dan gugus fungsional polar (Lehninger, 1982 dalam Sanger, 2008) dan formaldehyde memilki sifat polar (Teddy, 2007) sehingga formalin dapat larut dalam air, sehingga air PDAM dapat dijadikan aiternatif dalam menurunkan kadar formalin.

\section{Perbedaan Penurunan Kadar Formalin Ikan Tongkol Pada Rendaman Air Panas Suhu $50{ }^{\circ} \mathrm{C}$}

Tabel. 2

PENURUNAN KADAR FORMALIN IKAN TONGKOL SEBELUM DAN SESUDAH PERENDAMAN DENGAN AIR PANAS SUHU $50^{\circ} \mathrm{C}$

\begin{tabular}{|r|c|c|c|c|}
\hline \multirow{2}{*}{ No. } & \multicolumn{2}{|c|}{$\begin{array}{c}\text { Kadar Formalin Pada Ikan } \\
\text { Tongkol (mg/Kg) }\end{array}$} & $\begin{array}{c}\text { Perbedaan Kadar Formalin } \\
\text { Sebelum dan }\end{array}$ & $\begin{array}{c}\text { Penurunan Kadar Formalin } \\
\text { Sebelum dan Sesudah } \\
\text { Perendaman (\%) }\end{array}$ \\
\cline { 2 - 4 } & Sebelum (B) & Sesudah (B1) & Sesudah & 45.1 \\
\hline 1. & 98.24 & 53.92 & 44.32 & 45.8 \\
\hline 2. & 213.92 & 116.00 & 97.92 & 64.8 \\
\hline 3. & 208.80 & 73.44 & 135.36 & 63.9 \\
\hline 4. & 257.76 & 92.96 & 164.80 & 75.5 \\
\hline 5. & 198.76 & 48.80 & 149.96 & 80.4 \\
\hline 6. & 262.24 & 51.36 & 210.88 & 62.6 \\
\hline $\begin{array}{r}\text { Rata- } \\
\text { rata }\end{array}$ & 206.56 & 72.80 & 133.76 & \\
\hline
\end{tabular}

Berdasarkan uji Paired t test diperoleh hasil $p=0.002<a(0.05)$ yang menunjukkan bahwa ada perbedaan penurunan secara signifikan antara kadar formalin sebelum dan sesudah perlakuan perendaman pada air panas suhu $50^{\circ} \mathrm{C}$. Kemampuan air panas suhu $50{ }^{\circ} \mathrm{C}$ dalam menurunkan kadar formalin dikarenakan dalam proses perendaman dalam air panas, protein yang berikatan dengan formalin atau yang disebut dengan senyawa 
methylene dapat mengurai kembali menjadi protein dan formalin dengan adanya panas pada air (Purawisastra, 2011). Hal ini juga dipertegas oleh Budiarti (2009) bahwa proses pelarutan formalin dalam air makin cepat dengan meningkatnya suhu perendaman.

\section{Perbedaan penurunan Kadar Formalin Ikan Tongkol Pada Rendaman Air Cuka 5\%}

Tabel.3

PENURUNAN KADAR FORMALIN IKAN TONGKOL SEBELUN DAN SESUDAH PERENDAMAN DENGAN AIR CUKA $5 \%$

\begin{tabular}{|r|c|c|c|c|}
\hline \multirow{2}{*}{ No. } & \multicolumn{2}{|c|}{$\begin{array}{c}\text { Kadar Formalin Pada Ikan } \\
\text { Tongkol (mg/L) }\end{array}$} & $\begin{array}{c}\text { Perbedaan Kadar Formalin } \\
\text { Sebelum dan }\end{array}$ & $\begin{array}{c}\text { Penurunan Kadar Formalin } \\
\text { Sebelum dan Sesudah } \\
\text { Perendaman (\%) }\end{array}$ \\
\cline { 2 - 4 } & Sebelum (C) & Sesudah (C1) & Sesudah & 39.4 \\
\hline 1. & 142.40 & 86.40 & 56.36 & 30.8 \\
\hline 2. & 139.68 & 96.64 & 43.04 & 67.1 \\
\hline 3. & 145.60 & 48.00 & 97.60 & 68.5 \\
\hline 4. & 196.00 & 61.76 & 134.24 & 8.5 \\
\hline 5. & 145.12 & 132.80 & 12.32 & 40.2 \\
\hline 6. & 161.60 & 96.48 & 65.12 & 42.4 \\
\hline $\begin{array}{r}\text { Rata- } \\
\text { rata }\end{array}$ & 155.04 & 87.04 & 68.00 & \\
\hline
\end{tabular}

Berdasarkan uji Paired t test diperoleh hasil $\mathrm{p}=0.011<\mathrm{a}(0.05)$ yang menunjukkan bahwa ada perbedaan penurunan secara signifikan antara kadar formalin sebelum dan sesudah perlakuan perendaman pada air cuka $5 \%$.

Air cuka $5 \%$ dapat menurunkan kadar formalin pada ikan tongkol dikarenakan sumber asam dari cuka dapat mengkatalis proses pelepasan ikatan formalin dan protein (Wikanta, 2011), seperti yang dijelaskan oleh Riawan (1990) dalam Wikanta (2011) bahwa aldehid dapat dipisahkan dalam suatu campuran dengan menggunakan asam, Karena formalin merupakan salah satu turunan aidehida, maka ikatan protein-formalin dapat dipisahkan dengan cara hidrolisis melalui penambahan asam.

Perbandingan Penurunan Kadar Formalin Pada Ikan Tongkol Antar 3 Jenis Air Rendaman

Tabel.4

PERBANDINGAN PERSENTASE PENURUNAN KADAR FORMALIN PADA IKAN TONGKOL ANTAR 3 JENIS AIR RENDAMAN

\begin{tabular}{|c|c|c|c|c|c|c|c|}
\hline \multirow{2}{*}{$\begin{array}{c}\text { Kode } \\
\text { Sampel }\end{array}$} & \multicolumn{6}{|c|}{ Penurunan Kadar Formalin Pada Ikan tongkol (\%) Pada Pengulangan Ke - } \\
\cline { 2 - 8 } & 1 & 2 & 3 & 4 & 5 & 6 & $\begin{array}{c}\text { Rata- } \\
\text { rata }\end{array}$ \\
\hline A1 & 59.4 & 56.3 & 25.5 & 45.1 & 60.9 & 75.5 & 53.7 \\
\hline B1 & 45.1 & 45.8 & 64.8 & 63.9 & 75.5 & 80.4 & 62.6 \\
\hline C1 & 39.4 & 30.8 & 67.1 & 68.5 & 8.5 & 40.2 & 42.4 \\
\hline
\end{tabular}

Perbedaan penurunan kadar formalin dari berbagai jenis air rendaman dijelaskan oleh Nadeau dan Carlson (2005) dalam Wikanta (2011) bahwa besarnya kadar formalin yang dapat dihilangkan dalam ikan sangat tergantung pada jenis ikatan antara formalin dan protein ikan, formalin dapat berikatan dengan protein dalam bentuk methylene yang bersifat reversible. Senyawa methylene sendiri dapat terurai kembali menjadi protein dan formalin melalui reaksi hidrolisis (Teddy, 2007). Pelepasan senyawa methylene menjadi protein dan formalin sesuai dengan sifat formalin yang mudah larut dalam air. Pelarutan formalin dalam air dikarenakan formalin bersifat polar dan air dapat melarutkan senyawa organik yang mempunyai gugus karboksil/ amino dan gugus fungsional polar(Lehninger,1982 dalam Sanger,2008).

\section{Pengaruh Air Rendaman Terhadap Penurunan Kadar Formalin Pada Ikan Tongkol \\ Pengaruh jenis air rendaman terhadap penurunan kadar formalin pada ikan tongkol berdasarkan uji Anova diperoleh hasil $p=$}


$0.662>a(0.05)$ yang menunjukkan bahwa tidak ada pengaruh yang signifikan antara jenis air rendaman terhadap penurunan kadar formalin pada ikan.

Hal ini dikarenakan jenis air rendaman yang digunakan bahan utamanya adalah air yaitu air PDAM, Air PDAM yang dipanaskan sampai suhu $50{ }^{\circ} \mathrm{C}$ dan air cuka yang diencerkan sampai konsentrasi 5\%. Dimana dari penjelasan Lehninger (1982) dalam Sanger (2008) bahwa air dapat melarutkan senyawa organik yang mempunyai gugus karboksik/ amino dan gugus fungsional polar dan Teddy (2007) menjelaskan bahwa sifat dari formaldehyde adalah bersifat polar, sehingga formalin dapat larut dalam air. Formalin juga dapat larut dalam air cuka dikarenakan kandungan asam asetat dalam air cuka dapat bercampur dengan pelarut polar (Yuliarti,2011). Kemampuan formalin dapat larut dalam air dan air cuka yang menyebabkan kadar formalin dapat diturunkan menggunakan air dan air cuka.

Reaksi hidrolisis dalam penguraian kembali protein dan formalin pada senyawa methylene tidak terjadi secara spontan sehingga diperlukan adanya suatu tambahan energi , dan tambahan energi disini berupa panas (Purawisastra, 2011). Hal ini yang menjadi dasar bahwa perendaman menggunakan air yang dipanaskan sampai suhu $50{ }^{\circ} \mathrm{C}$ dapat menurunkan kadar formalin lebih banyak dibandingkan dengan air PDAM. Oleh karenanya perbedaan jenis air rendaman sebagai air rendaman tidak memiliki pengaruh yang signifikan terhadap penurunan kadar formalin, sehingga ketiga jenis air rendaman tersebut dapat dijadikan sebagai alternatif oleh masyarakat untuk menurunkan kandungan formalin pada ikan segar, khususnya ikan tongkol.

\section{KESIMPULAN}

Presentase penurunan kadar formalin pada ikan tongkol yang direndam pada 3 jenis air rendaman selama 30 menit didapatkan hasil yang berbeda yaitu, pada kelompok A1 rendaman air PDAM mampu menurunkan kadar formalin sebesar $53.7 \%$ dan pada kelompok B1 rendaman air panas suhu $50^{\circ} \mathrm{C}$ dapat menurunkan kadar formalin sebesar $62.6 \%$, sedangkan pada kelompok $\mathrm{C} 1$ rendaman air cuka $5 \%$ dapat menurunkan kadar formalin sebesar $42.2 \%$. berdasarkan uji paired $t$ test dari 3 jenis air rendaman tersebut memilki perbedaan penurunan secara signifikan antara kadar formalin sebelum dan sesudah perlakuan perendaman. Pada uji pengaruh air rendaman terhadap penurunan kadar formalin pada ikan tongkol menggunakan uji anova diperoleh hasil diperoleh hasil $\mathrm{p}=0.662>a(0.05)$ yang menunjukkan bahwa tidak ada pengaruh jenis air rendaman terhadap penurunan kadar formalin pada ikan tongkol, sehingga masyarakat dapat menggunakan ketiga jenis air rendaman dalam menurunkan kadar formalin pada ikan tongkol yang berformalin.

\section{SARAN}

Saran bagi masyarakat yaitu sebaiknya masyarakat dapat melakukan pengolahan pada ikan segar sebelum dikonsumsi berupa perebusan dikarenakan perebusan dapat menurunkan kandungan formalin yangt terdapat pada ikan segar, khususnya ikan tongkol. Saran bagi peneliti selanjutnya yaitu perlu diadakan penelitian lanjutan pada sampel ikan yang lain dan konsentrasi air rendaman serta waktu rendaman yag berbeda. Saran bagi dinas terkait yaitu diharapkan ada upaya penyuluhan kepada masyarakat tentang bahaya formalin bagi kesehatan dan ciri cirri makanan yang mengandung formalin sehingga masyarakat dapat memilih bahan makanan yang sehat secara bijak.

\section{DAFTAR PUSTAKA}

Budiarti, Agnes, Supriyadi dan Siti Musinah, 2009. Pengaruh Perendaman Dalam Air Hangat Terhadap Kandungan formalin Pada Mie Basah Dari Tiga Produsen Yang Dijual Di Pasar Johar Semarang. IImu Farmasi dan Farmasi Klinik, Volume 6.

Cahyadi, Wisnu, 2009. Analisis dan Aspek Kesehatan Bahan Tambahan Pangan. Jakarta, Bumi Aksara.

Direktorat Jenderal Pengolahan dan Pemasaran Hasil Perikanan, 2013. Pulau Jawa, Pasar Potensial untuk Hasil Perikanan, Warta Pasar Ikan http://www.wpi.kkp.go.id/?p=115 . 3 Januari 2014

Ilmu Pengetahuan dan Research, 2012. Awas Bahaya Frmalin Pada Makanan. http://www.ot.co.id/Research life.aspx? Research id=13. 15 Desember 2013.

Peraturan Menteri Kesehatan Republik Indonesia Nomor : 003 Tahun 2012 Tentang Bahan Tambahan Pangan.

Purwisastra, Suryana dan Emma Sahara,2011. Penyerapan Formalin Oleh Beberapa Makanan Serta Penghilangannnya Melalui Perendaman Dalam Air Panas. Penel Gizi Makan, Volume 34.

Sanger, Grace dan Litha Mpntlalu. 2008. Metode Pengurangan Kadar Formalin Pada Ikan Cakalang (Kasuwnus pelamis). Warta Wiptek, Edisi 32.

Teddy, 2007. Pengaruh Konsentrasi Formalin Terhadap Keawetan Bakso Terhadap Residu Formalinnya. Fakultas Teknologi Pertanian, Institut Pertanian Bogor, Bogor. 